the numerical solution of equations describing the motion and heat balance of the atmosphere when values from meteorological observations are substituted. In this way, the way in which conditions in the atmosphere will change for a day or two ahead can be forecast. For a forecast extending only 24 hours into the future, however, 8 hours of computing time on Atlas are needed. The results have been encouraging, the Meteorological Office says, but, to put this work on an operational footing, a really large computer is needed.

One of the five manufacturers which the Meteorological Office sees as suppliers of its new machine is International Computers Limited, the company formed in March this year by International Computers and Tabulators, English Electric and Plessey. Presumably the latest machine from ICL-the $1908 \mathrm{~A}$-announced in August and available in a form having up to twenty times the power of Atlas, will be one of the chief contenders. The other four firms are American, and whether the Meteorological Office will be allowed to buy from them when a British machine is available is an open question. The philosophy at Bracknell just now is to go ahead with the sounding of the British and American manufacturers and see what happens.

\section{ROAD SAFETY}

\section{Health on the Roads}

IN the future, British automobile drivers may have to be medically screened when they apply for a licence if a memorandum from the British Medical Association is approved by the Ministry of Transport. The BMA proposes that the application forms for driving licences should include questions about illnesses or absence from work lasting more than six weeks during the previous ten years and when the licence is renewed drivers would have to disclose illnesses since the licence was last granted. In certain cases, the medical adviser to the local licensing authority would approach the hospital or the patient's family doctor for more information about the driver-the driver would have to give his assent to his doctor for these disclosures to be made at the time the application was made. Elderly drivers who wear spectacles may be asked to produce a certificate from an ophthalmologist.

Local authorities, according to the memorandum, would have discretion to decide which drivers needed a medical examination and could refuse to grant licences in certain cases. Drivers would, however, be allowed to appeal against this ruling, and the BMA proposes the setting up of regional medical panels to deal with doubtful or disputed cases.

The idea for medical screening of drivers was broached at the annual meeting of the British Medical Association in June this year. The Private Practice Committee of the association then set out a scheme and this was recently approved by the BMA council and sent to the Ministry of Transport.

Little is known about the relationship between physical disability and the causation of road accidents, and the British Medical Journal (October 12, 69; 1968) comments that it is "unlikely that many more licences will be refused than are at present. As the body of information accumulates, it should be possible to correlate accident rates with diagnostic categories, and in time a policy could be developed which is supported by reliable scientific evidence". The Ministry of Transport is meanwhile considering the memorandum in connexion with the revision of licence application forms in association with the introduction in the 1970 s of a central system for driving licences and vehicle registrations.

\section{MINING ENGINEERING \\ Saving the lost Tin}

The Science Research Council announced last week that it had awarded a grant of $£ 14,638$ over the next three years to a nuclear physicist, Professor G. F. Powell of Bristol University, to support research into improvements in methods of extracting tin from its ores. All this may sound a most unlikely combination, but the grant is a small example of the SRC's new policy of preferentially increasing support to applied research (see page 216 of this issue). In fact the grant is going to support Dr C. R. Burch and Mr R. Mozley at the Wills Physics Laboratory, who have, since 1965, devised a machine which improves extraction of cassiterite (tin oxide) from crude ore and which is already saving one of the two remaining Cornish tin mines about $\mathfrak{f 5 0 , 0 0 0}$ a year.

The development of this machine is an example of the sort of project which is likely to become increasingly common now that the SRC is turning to applied research and the NRDC has a realistic budget. In $1965 \mathrm{Mr}$ Mozley, a mining engineer, joined Dr Burch, then two years away from retirement, as his research assistant and immediately began building a prototype ore concentrator at the Geevor tin mine near Land's End. Crude tin ore contains about one per cent cassiterite and much of this is lost with the conventional gravity concentrators, which cannot recover particles less than $50 \mu$ in diameter. Mr Mozley had an idea how to improve recovery, but, as he says, it is no use trying to change the ways of traditionally minded mining engineers by showing them models, and so from the outset he had to build a full scale prototype. The machine worked; it recovered particles down to $5 \mu$ in diameter and increased overall recovery from about 79 per cent to 81 per cent. That may sound not very much, but with tin costing $£ 1,300$ a ton it makes a great difference to the profit of a mine. In fact the Geevor mine was so pleased with the machine that it built six copies of the

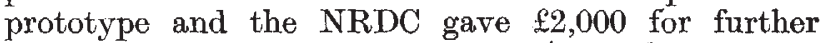
development, took out patents and has sold a licence to a company to build commercial models. These are finding a ready market with the companies which are reworking the waste tips of a number of Cornish mines that closed in the 1920s.

The SRC came into the act this year because, like many successful inventions before it, no one is quite sure how the Mozley-Burch concentrator works. The SRC baulked at the prospect of providing funds for building prototypes of an improved version, saying, quite properly, that that is the province of the NRDC with which renewed negotiations are under way, but it has provided $£ 14,000$ to support work on the physical principles of the concentrator. As far as is known, Bagnold forces are probably responsible for its suecess. A $1 \mathrm{~mm}$ thick film of crushed ore, suspended in water, flows over a large flat surface of resin bonded fibre glass 
suspended by wires from a rigid frame, which is kept in orbital motion by a rotating weight attached underneath. The orbital motion shears the film and sets up a shear gradient in it. Bagnold found in his studies of particle motion in deserts that, under such conditions, forces acting on the particles and at right angles to the gradient-in other words vertical forces-develop, and these are proportional to the particle size but not to the density. The net effect, of course, is that the small dense cassiterite particles come out of suspension and can be collected.

Whether or not this turns out to be how the machine works, the research is bound to lead to a better understanding of the physics of ore separation and better machinery, both of which are certainly needed now that low grade ores are having to be exploited.

\section{ARCHAEOLOGY Norman Castle at York}

\section{from our Archaeology Correspondent}

A ReCONNAISSANCe excavation at Baile Hill just within the city walls at York, directed by Mr P. V. Addyman, of Southampton University and sponsored by the Royal Archaeological Institute as part of its programme to investigate the origins of the castle in England, has almost certainly identified the hill as the partly denuded motte of one of the two castles built in York by William I in 1068 or 1069. Recently (Nature, 219, 1214; 1968), Dr B. K. Davison's new theory of the origin of the motte and bailey castle was outlined, namely that the design evolved in England after the Norman Conquest, and his prediction that the earliest mottes could well have been built on top of earlier Norman earth ringworks. Both the castles built in York within three years of the Conquest were taken in September 1069 during the Anglo-Danish uprising against William and partially destroyed, but then promptly retaken by William and repaired. One of the castles was continuously occupied and extended throughout the middle ages and remains as York castle; the other, as it turns out, on the Baile Hill site had fallen into disuse by the thirteenth century and the large number of mediaeval arrow heads found during the excavation suggests that the site was used thereafter chiefly as an archery butt. Because the Baile Hill castle was built immediately after the Conquest and not in use for very long, on the face of things it is probably the best site in England for discovering the layout of the earliest motte and bailey castles and could prove a crucial test of Davison's theory.

The crucial question as far as Dr Davison's theory is concerned is whether the motte was the primary or a secondary Norman structure on Baile Hill. The excavation so far has not provided an unequivocal answer, but it does seem certain that the motte was built before 1100. So far the trench at the base of the motte has been uncovered as well as a flight of steps formed in the clay of the mound, which were so freshly preserved that they were once probably faced with wood. The steps presumably led from the bailey to the summit of the motte and the trench was in all probability bridged by a horizontal wooden bridge. During the excavation of these steps the ground surface on which the motte was raised was revealed. It contained no pottery that can be dated to later than 1100 but plenty of Saxon pottery (Thetford, Stamford and York ware) as well as a fourth century Roman pit. The motte must thus have been built before 1100 , but until further excavations at the base of the motte have been made it is impossible to rule out the possibility that there are earlier Norman ringworks on the site. The chances are, however, that the motte is the primary structure.

Excavation of a small area on the summit of the motte revealed a cobbled surface, probably laid when the motte was built, overlain by several feet of earth containing abundant Saxo-Norman pottery and objects of the eleventh and twelfth centuries and traces of the Royalist battery built during the Civil War. The Norman cobbled area did not extend to the head of the flight of stairs, so presumably this area was covered by an entrance building, but the area excavated was too small to reveal any foundations of Norman buildings. The site is, however, sufficiently well preserved to merit further excavations which are planned for next summer. The only problem is that the mediaeval town walls and a modern road abut Baile Hill and so excavation for the possible ringwork will be expensive.

\section{New Burdens for Science Reseurch Council}

THe last eighteen months have been a trying time for the Science Research Council. First, its budget has not been increased by anywhere near as much as everyone hoped; in 1967-68, the council spent nearly $\mathfrak{f}_{38.6}$ million (see Table 1) compared with $\mathfrak{£} 34 \cdot 3$ million in the previous financial year. Second, as Professor B. Flowers, the council's chairman, said when he introduced the third annual report on October 10 (HMSO, $7 s .6 d$.), the council has witnessed its "biggest negative achievement ever". He meant, of course, the British Government's injudicious decision, taken in the face of the council's advice, not to participate in building the CERN $300 \mathrm{GeV}$ accelerator. The $5 \mathrm{GeV}$ accelerator NINA at Daresbury, which was commissioned this year, is no substitute, and the council, refusing to be reconciled to the CERN decision, has pledged itself to continue to press for a reversal.

The SRC is, however, in agreement with the Government and the Swann Committee over the general policy of increasing preferentially support to applied research. This is apparently the council's own view, reached without prompting from the Government or anyono else. At the end of 1967 the SRC started a major review of its general policy, and as a result has decided that although it will continue to support research on a broad front it will concentrate on work likely to yield the most significant scientific advance or to be the bassis of social or economic benefit to Britain. This will 